\title{
Carrot seed germination and ethylene production at high temperature in response to seed osmopriming
}

\author{
Warley M Nascimento ${ }^{1}$; Donald J Huber ${ }^{2}$; Daniel J Cantliffe ${ }^{2}$ \\ 'Embrapa Hortaliças, C. Postal 218, 70351-970 Brasília-DF, Brazil; warley.nascimento@embrapa.br; ${ }^{2}$ University of Florida, Institute of \\ Food and Agricultural Sciences, Horticultural Sciences Department, 1251 Fifield Hall, PO Box 110690, Gainesville, FL 32611-069
}

\begin{abstract}
Carrot (Daucus carota) seed germination can be erratic or reduced under temperatures above $35^{\circ} \mathrm{C}$. Priming circumvents seed thermoinhibition in several crops, including carrot. The involvement of ethylene in germination at supra-optimal temperatures has been reported in other species, but its role in carrot seed germination has not been examined. The objective of this study was to determine whether priming-mediated improvement in carrot seed germination at high temperature was associated with increased ethylene production. Seeds of two tropical carrot genotypes (Alvorada and Brasília) were incubated over a range of temperatures. 'Brasilia' seeds were primed for 72 hours in aerated PEG solution at $15^{\circ} \mathrm{C}$ under light conditions and germination tested at 20 and $35^{\circ} \mathrm{C}$. Seeds of a thermosensitive genotype 'Arrowhead' were primed for $0,4,8$ and 12 days in aerated PEG 6000 solutions at $15^{\circ} \mathrm{C}$ under light conditions. Seeds were incubated at 20 and $35^{\circ} \mathrm{C}$, and ethylene production was measured immediately before visible primary root protrusion. Temperatures above $30^{\circ} \mathrm{C}$ decreased seed germination percentage of 'Alvorada' and 'Brasilia'. Priming increased 'Brasilia' seed germination at $35^{\circ} \mathrm{C}$. 'Arrowhead' germinated $96 \%$ at $20^{\circ} \mathrm{C}$, and $13 \%$ at $35^{\circ} \mathrm{C}$. Seed germination and ethylene production of 'Arrowhead', a thermosensitive genotype, increased in response to increased duration of priming. The results suggest that seed priming circumvents thermoinhibition of carrot seed germination by increasing ethylene production at high temperatures.
\end{abstract}

Keywords: Daucus carota, thermotolerance, stand establishment, osmoconditioning, cultivars.

\section{RESUMO}

Germinação de sementes de cenoura e produção de etileno em alta temperatura em resposta ao osmocondicionamento

A germinação de sementes de cenoura (Daucus carota) pode ser irregular ou reduzida em temperaturas superiores a $35^{\circ} \mathrm{C} . \mathrm{O}$ condicionamento osmótico contorna a termo-inibição de sementes de diversas espécies, incluindo a cenoura. $\mathrm{O}$ envolvimento de etileno na germinação de sementes em temperaturas supra-ótimas tem sido relatado em outras espécies, mas o seu papel na germinação de sementes de cenoura não tem sido investigado. O objetivo deste estudo foi determinar se a tolerância de sementes osmocondicionadas de cenoura à germinação sob altas temperaturas está associada ao aumento da produção de etileno. Sementes de dois genótipos de cenoura (Alvorada e Brasília) foram incubadas em várias temperaturas. Sementes de 'Brasília' foram condicionadas por $72 \mathrm{~h}$ em soluções aeradas de PEG 6000 a $15^{\circ} \mathrm{C}$ sob luz e, em seguida, incubadas a 20 e $35^{\circ} \mathrm{C}$. Sementes de 'Arrowhead', genótipo termo-sensível, foram condicionadas por $0,4,8$ e 12 dias em solução aerada de $\mathrm{PEG}$ a $15^{\circ} \mathrm{C}$ sob luz. As sementes foram incubadas a 20 e $35^{\circ} \mathrm{C}$ e a produção de etileno foi determinada imediatamente antes da emissão visível da raiz primária. Temperaturas superiores a $30^{\circ} \mathrm{C}$ prejudicaram a germinação de sementes de 'Alvorada' e 'Brasília'. O condicionamento osmótico beneficiou a germinação das sementes de cenoura 'Brasília', a $35^{\circ} \mathrm{C}$. Sementes de cenoura 'Arrowhead' germinaram $96 \%$ a $20^{\circ} \mathrm{C}$, e $13 \%$ a $35^{\circ} \mathrm{C}$. A germinação de sementes e produção de etileno no genótipo termo-sensível 'Arrowhead', aumentaram em resposta ao aumento da duração do condicionamento osmótico. Os resultados sugerem que o condicionamento osmótico contorna a termo-inibição das sementes de cenoura pelo aumento da produção de etileno em condições de altas temperaturas.

Palavras-chave: Daucus carota, termotolerância, estabelecimento de plântulas, condicionamento osmótico, cultivares.

(Recebido para publicação em 10 de fevereiro de 2013; aceito em 11 de outubro de 2013) (Received on February 10, 2013; accepted on October 11, 2013)

$\mathrm{C}$ arrot crops are established by direct seeding, and poor stands may occur when sowing is done during extremely high temperatures. Many publications relate the negative effects of high temperatures $\left(35-40^{\circ} \mathrm{C}\right)$ on carrot stand establishment (Cantliffe \& Elballa, 1994; Vieira et al., 2005; Nascimento \& Pereira, 2007; Pereira et al., 2007; Nascimento et al., 2008). In tropical areas, carrot production is vulnerable to loss due to thermal stress during stand establishment (Vieira et al., 2005), and most commercial carrot cultivars have reduced seed germination at high temperatures.

Seed priming has been shown to be an effective treatment for the improvement of carrot stand establishment (Szafiroswska et al., 1981; Brocklehurst \& Dearman, 1983; Cantliffe \& Elballa, 1994; Nascimento
\& Pereira, 2007). Priming is based on seed hydration under conditions that allow the occurrence of metabolic activity but prevent cellular elongation and primary root emergence. The success of osmotic priming depends on several factors including duration of soaking.

The role of ethylene in seed germination has been extensively studied in several species (Abeles et al., 1992), 
and it was observed that ethylene may be involved in the removal of inhibitors and thus de-repress germination (Bewley et al., 2013), especially under stress conditions. In lettuce, it has been suggested that ethylene is necessary for germination at supra-optimal temperatures (Nascimento et al., 2000, 2004; Kozareva et al., 2004, 2006). Nascimento et al. (2008) verified that the ability of carrot seeds to germinate at high temperatures is genotypedependent, and the thermotolerant genotypes identified in that study might be useful for incorporating thermotolerance traits into breeding programs.

The involvement of ethylene in carrot seed germination, especially under stress conditions, has not been examined. The objective of this study was to determine whether primingeffects in carrot seed germination at high temperature was associated with increased ethylene production.

\section{MATERIAL AND METHODS}

Germination at range of temperatures using two sub-tropical cultivars

Plant material - Seeds of two lots from 'Brasília' and 'Alvorada' (Embrapa Vegetables) were used in this study. These cultivars are considered as intermediate in terms of thermotolerance trait (Nascimento et al., 2008).

Germination test - Four replications of 25 seeds each were placed on two layers of $5.0 \mathrm{~cm}$ diameter germination paper (Anchor Paper, Hudson, WI) moistened with $3 \mathrm{~mL}$ of distilled water. Blotters were covered with $5.5 \mathrm{~cm}$ petri dish lids and incubated under constant light (fluorescent $\sim 26 \mu \mathrm{mol} \mathrm{m} \mathrm{m}^{-2} \mathrm{~s}^{-1}$ ) on a one-dimensional thermogradient bar (Type DB 5000, Van Dok \& De Boer, B.V., Holland) at temperatures ranging from 20 to $40^{\circ} \mathrm{C}$. Germination was defined as visible radicle protrusion through the seed coat and was evaluated daily during 10 days of incubation.

\section{Priming effect using a sub-tropical cultivar}

Plant material - 'Brasília' carrot seeds from Embrapa Vegetables,
Brasilia, Brazil, were used in this study.

Seed priming - Seeds were primed in $200 \mathrm{~mm}$ test tubes for 72 hours at $15^{\circ} \mathrm{C}$ with constant light $\left(\sim 26 \mu \mathrm{mol} \mathrm{m} \mathrm{m}^{-2} \mathrm{~s}^{-1}\right)$ in an aerated solution of polyethylene glycol (PEG 6000) at an osmotic potential of $-1.2 \mathrm{MPa}\left(30 \mathrm{~mL} \mathrm{~g}^{-1}\right.$ of seed). An aquarium pump provided aeration. The air was pre-hydrated by passing through water to minimize evaporation of the priming solution. Afterward, seeds were placed in a Buchner funnel, washed three times with $100 \mathrm{~mL}$ of distilled water and redried in an incubator at $15^{\circ} \mathrm{C}$ and $45 \% \mathrm{RH}$ for two days.

Seed germination - Three replications of 25 seeds were placed in $5.5 \mathrm{~cm}$ petri dishes with two layers of $4.5 \mathrm{~cm}$ diameter \#3 filter paper (Anchor Paper) moistened with $4 \mathrm{~mL}$ of distilled water. Additional distilled water was added as needed to keep the filter paper moist. Seeds were incubated under constant light (30

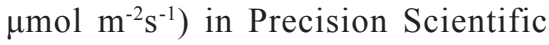
incubators (Winchester, VA, USA) at $20^{\circ} \mathrm{C}$ (optimal) and $35 \pm 0.5^{\circ} \mathrm{C}$ (adverse), generating the total germination at $20^{\circ} \mathrm{C}$ (TG 20) and $35^{\circ} \mathrm{C}$ (TG 35), as well as the germination rate at $20^{\circ} \mathrm{C}$ (GR 20 ) and $35^{\circ} \mathrm{C}$ (GR 35). Germination was defined as visible primary root protrusion through the seed coat at 10 days of incubation. Germination rate was also evaluated daily during 10 days of incubation using the Maguire (1962) formula, where $\mathrm{GR}=\mathrm{N} 1 / \mathrm{D} 1+\mathrm{N} 2 /$ $\mathrm{D} 2+\ldots+\mathrm{Nn} / \mathrm{Dn}, \mathrm{N}$ is the germinated seeds, and D is the number of days for germination.

Priming duration and ethylene production at high temperature

Plant material - A thermosensitive genotype ('Arrowhead'), from Sakata Seed Co. was used in this study.

Seed priming - Seeds were primed in $200 \mathrm{~mm}$ test tubes for $0,4,8$ and 12 days at $15^{\circ} \mathrm{C}$ with constant light $(\sim 26$ $\left.\mu \mathrm{mol} \mathrm{m} \mathrm{m}^{-2} \mathrm{~s}^{-1}\right)$ in an aerated solution of polyethylene glycol (PEG 6000) at an osmotic potential of $-1.2 \mathrm{MPa}(30 \mathrm{~mL}$ $\mathrm{g}^{-1}$ of seed). An aquarium pump provided aeration. The air was pre-hydrated by passing through water to minimize evaporation of the soaking solution.
Afterward, seeds were placed in a Buchner funnel, washed three times with $100 \mathrm{~mL}$ of distilled water and redried in an incubator at $15^{\circ} \mathrm{C}$ and $45 \% \mathrm{RH}$ for two days.

Germination test - Three replications of 25 seeds were incubated at 20 and $35^{\circ} \mathrm{C}$ using the procedures described above.

Ethylene determination - Three replications of $0.1 \mathrm{~g}$ of dry seeds were placed on two layers of $3.0 \mathrm{~cm}$ diameter germination paper in $50 \mathrm{~mL}$ vials. The filter paper was moistened with $4 \mathrm{~mL}$ of distilled water, the vials sealed with caps fitted with septa, and incubated under the same conditions as the standard germination procedures. After 12 hours (preliminary results indicated 12 hour-incubation, i.e, immediately before visible radicle protrusion as the ideal time), ethylene production was determined. A $1 \mathrm{~mL}$ gas sample was withdrawn with a gas-tight hypodermic syringe (Fisher Scientific). Ethylene was assayed using a Hewlett Packard Series II 5890 gas chromatograph (Hewlett Packard, Agilent Technologies, Foster City, CA) equipped with a flame ionization detector. The carrier gas was nitrogen. The oven, injector and detector were at $130^{\circ} \mathrm{C}, 110^{\circ} \mathrm{C}$, and $150^{\circ} \mathrm{C}$, respectively.

Statistical analysis - Analysis of variance was performed with the Genes Program (Cruz, 2006), and the characters of total germination and germination rate were transformed by $(x+0.50) 1 / 2$ in order to attend the normality presupposition of Lilliefors test. The means were compared through the Tukey test.

\section{RESULTS AND DISCUSSION}

Temperatures above $30^{\circ} \mathrm{C}$ caused decreases in seed germination of both 'Brasília' and 'Alvorada' (Figure 1). The negative effects of high temperatures on carrot seed germination and consequently stand establishment have been previously observed in these tropical genotypes (Pereira et al., 2007). However, in another study, 'Alvorada' and 'Brasilia' along with XPC-3617 (Sakata) had the greatest germination 


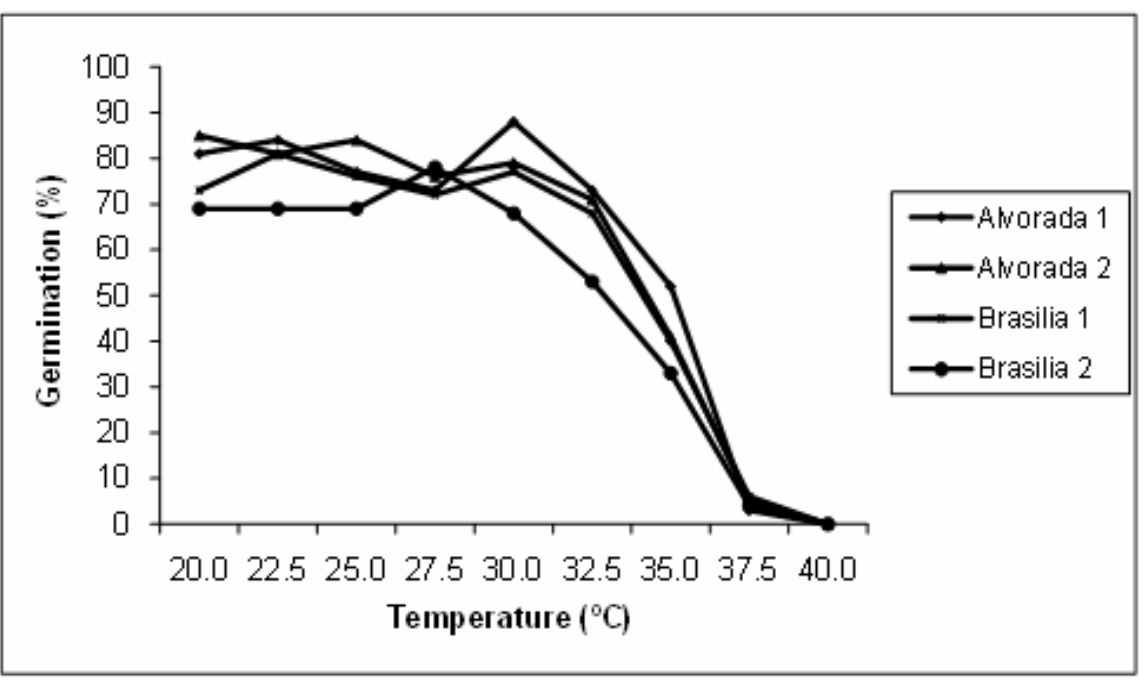

Figure 1. 'Alvorada' and 'Brasilia' carrot seed germination at a range of temperatures (germinação de sementes de cenoura 'Alvorada' e 'Brasília' em diferentes temperaturas). Gainesville, University of Florida, 2007.

Table 1. Germination rate (GR) and total germination (TG) of 'Arrowhead' carrot seeds incubated at 20 and $35^{\circ} \mathrm{C}$ after different priming periods (velocidade de germinação (GR) e germinação total (TG) de sementes de cenoura 'Arrowhead' incubadas a 20 e $35^{\circ} \mathrm{C}$ após diferentes períodos de condicionamento osmótico). Gainesville, University of Florida, 2007.

\begin{tabular}{lcccc}
\hline Period (days) & GR20 (days) & TG20 (\%) & GR35 (days) & TG35 (\%) \\
\hline 0 & $2.9 \mathrm{a}^{\mathrm{z}}$ & $96 \mathrm{ab}$ & $6.8 \mathrm{a}$ & $13 \mathrm{c}$ \\
4 & $2.5 \mathrm{~b}$ & $92 \mathrm{~b}$ & $4.4 \mathrm{ab}$ & $66 \mathrm{~b}$ \\
8 & $1.9 \mathrm{c}$ & $99 \mathrm{ab}$ & $2.4 \mathrm{~b}$ & $96 \mathrm{a}$ \\
12 & $1.7 \mathrm{c}$ & $100 \mathrm{a}$ & $1.9 \mathrm{~b}$ & $97 \mathrm{a}$ \\
\hline $\mathrm{CV}(\%)$ & 4.87 & 3.13 & 25.54 & 8.28 \\
\hline
\end{tabular}

${ }^{\mathrm{z}}$ Means within a column followed by different letters are significantly different at $p \leq 0.05$ according to Tukey test (médias seguidas por letras diferentes na coluna são significativamente diferentes a $\mathrm{p}<0,05$ pelo teste de Tukey).

under high temperature; also they showed the highest thermotolerance ratio $\left(T h / T o\right.$, where $T h=$ germination at $35^{\circ} \mathrm{C}$, supra-optimal and $T o=$ germination at $25^{\circ} \mathrm{C}$, optimal), (Nascimento et al., 2008). The variation in percentage of germination at high temperature observed between the seed lots in the present study was possibly due to inherent differences in seed vigor. In another study (data not shown), carrot seeds from a thermotolerant genotype (XPC-3617) germinated $100 \%$ at both 20 and $35^{\circ} \mathrm{C}$; however, when seeds were artificially aged $\left(41^{\circ} \mathrm{C} / 1\right.$ day), the germination remained $100 \%$ at $20^{\circ} \mathrm{C}$, but declined to $82 \%$ at $35^{\circ} \mathrm{C}$, showing that seeds of high vigor show higher tolerance to environmental stresses, including high temperatures.
Nascimento et al. (2005) verified that aged lettuce seeds germinated poorly at $35^{\circ} \mathrm{C}$ compared with unaged seeds. Furthermore, seed aging can lead to physiological and biochemical changes including reduced ethylene production and endo- $\beta$-mannanase activity, factors possibly contributing to thermoinhibited seed germination. Ethylene production during germination was also observed in aged tomato seeds compared with nonaged seeds (Siriwitayawan et al., 2003). In addition, seeds from the sub-tropical cultivars 'Alvorada' and 'Brasília' generally have lower germination at optimal temperatures compared to imported commercial cultivars (Pereira et al., 2007). In open pollinated cultivars such as 'Brasilia', there is still high genetic diversity, which is one reason why seed quality standards do not appear to be very well defined, leaving high variation in seed quality in terms of germination and vigor (Vieira et al., 2005). These physiological seed quality traits may compromise crop establishment especially under conditions such as high temperatures at imbibition.

Seed priming may be effective to favor carrot seed germination at high temperatures. Priming of 'Brasilia' seed, however, was of limited success in improving germination at high temperature. At $35^{\circ} \mathrm{C}$ unprimed and primed seeds germinated at $35 \%$ and $65 \%$, respectively (data not shown). Germination at $20^{\circ} \mathrm{C}$ in both primed and unprimed seeds was $82 \%$. As cited above, the physiological quality of those genotypes such as 'Brasilia' group is lower when compared to other commercial carrot cultivars and this may have affected the better response to seed priming.

The low response to seed priming in this study was possibly due to the short period of soaking during priming. In another study, Nascimento et al. (2013) observed that extended priming duration may benefit results at high temperature from carrot seed priming. Accordingly, priming duration was examined for its influence on germination of thermosensitive carrot seed at high temperatures. The results are shown in Table 1. Germination of unprimed seeds was $96 \%$ at $20^{\circ} \mathrm{C}$ and $13 \%$ at $35^{\circ} \mathrm{C}$. Priming increased germination rate and total germination at both temperatures, and improved germination responses were observed in response to longer priming duration. For example, priming periods of 4,8 , and 12 days resulted in total germination at $35^{\circ} \mathrm{C}$ of $66 \%, 96 \%$, and $97 \%$, respectively. At $25^{\circ} \mathrm{C}$ germination rate was 2.9 days in unprimed seeds and 1.7 days in seeds primed for 12 days; at $35^{\circ} \mathrm{C}$ germination rate was 6.8 days in unprimed seeds and 1.9 days in seeds primed for 12 days (Table 1). Thus, extending the duration of seed priming proved highly effective for improving seed germination at high temperature.

No ethylene production was observed in unprimed seeds at 20 and $35^{\circ} \mathrm{C}$ 


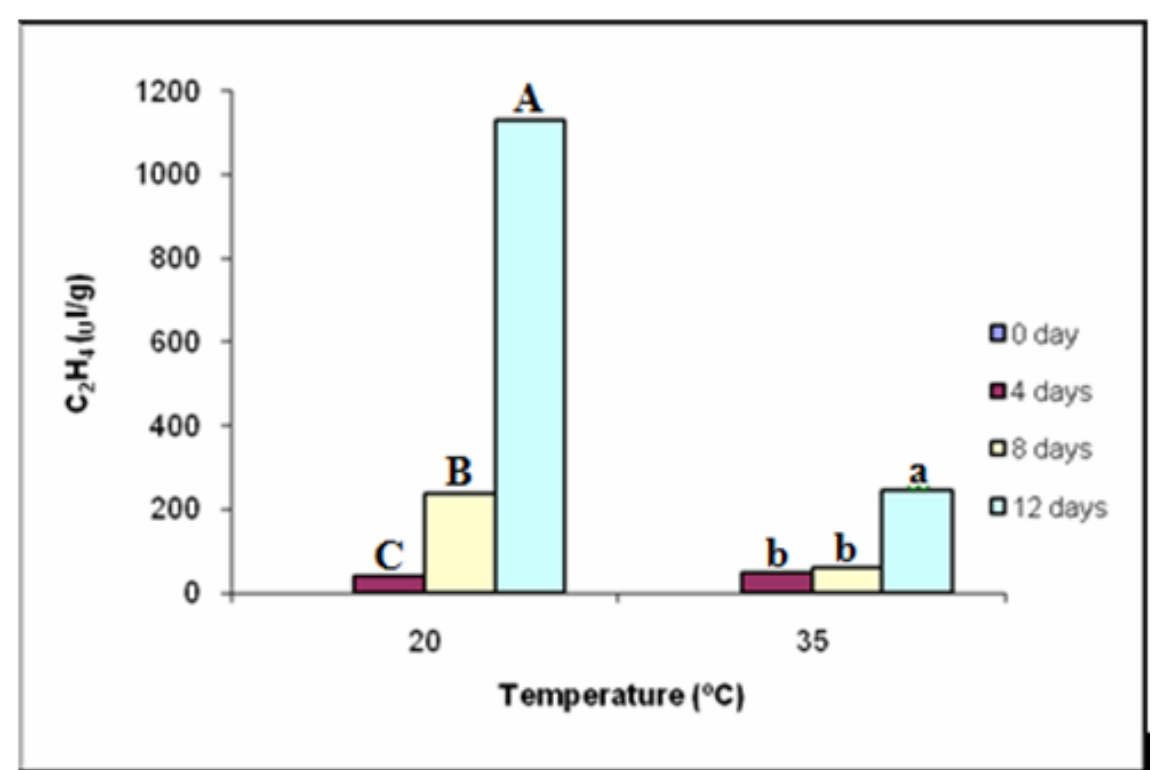

Figure 2. Ethylene production of 'Arrowhead' carrot seeds incubated at 20 and $35^{\circ} \mathrm{C}$ after different priming periods $(0,4,8$ and 12 days). Means followed by the same uppercase letter and the same lowercase letter were not significantly different by Tukey test at $p<0.05$ [produção de etileno de sementes de cenoura 'Arrowhead' incubadas a 20 e $35^{\circ} \mathrm{C}$ após diferentes períodos de condicionamento osmótico (0, 4, 8 e 12 dias). Médias seguidas pela mesma letra maiúscula e mesma letra minúscula não são significativamente diferentes $(\mathrm{p}<0,05)$ pelo teste de Tukey]. Gainesville, University of Florida, 2007.

(Figure 2). For primed seeds, ethylene production was lower at $35^{\circ} \mathrm{C}$ than at $20^{\circ} \mathrm{C}$. High temperatures have been shown to inhibit ethylene production in lettuce seeds (Nascimento et al., 2000). Ethylene production increased markedly in response to priming and priming duration. It is not clear, however, whether the increased ethylene production in response to priming was simply due to increased seed vigor. Nascimento et al. (2005) verified that aged lettuce seeds germinated poorly at $35^{\circ} \mathrm{C}$ compared with unaged seeds and that seed aging reduced ethylene production during subsequent seed germination. In tomato, priming was accompanied by a significant increase in ethylene production during radicle protrusion compared with non-primed seeds (Siriwitayawan et al., 2003). The authors suggested that priming reduced the time required to initiate synthesis and/or activity of both ACC-synthase and ACC-oxidase. In our study, ethylene production was measured after 12 hours of imbibition (immediately before visible radicle protrusion). Thus, a possible mechanism of seed priming in circumventing thermoinhibition of carrot seeds would be by increasing support, process no. 470782/2004-8.

\section{REFERENCES}

ABELES FB; MORGAN PW; SALTVEIT JUNIOR ME. 1992. Ethylene and plant biology, $2^{\text {nd }}$ ed. San Diego: Academic Press. 414p.

BEWLEY, JD; BRADFORD KJ; HILHORST HWM; NONOGAKI H. 2013. Seeds: Physiology of development, germination and dormancy, $3^{\text {rd }}$ ed. New York: Springer. 392p.

BROCKLEHURST PA; DEARMAN J. 1983. Interactions between seed priming treatments and nine seed lots of carrot, celery and onion. I. Laboratory germination. Annals of Applied Biology 102: 577-584.

CANTLIFFE DJ; ELBALLA M. 1994. Improved germination of carrot at stressful high temperature by seed priming. Proceedings of the Florida State Horticultural Society 107: 121-128.

CRUZ CD. 2006. Programa genes: aplicativo computacional em genética e estatística. Viçosa: UFV. 648p.

KOZAREVA I; CANTLIFFE DJ; NAGATA RT; KLEE HJ. 2004. New support for the involvement of ethylene in lettuce germination at supra-optimal temperature. Acta Horticulturae 631: 31-37.

KOZAREVA I; CANTLIFFE DJ; NAGATA RT; STOFFELLA PJ. 2006. High maturation temperature of lettuce seeds results in increased ethylene production and germination at elevated temperatures. Journal of the American Society for Horticultural Science 131: 564-570.

MAGUIRE JD. 1962. Speed of germinationaid in selection and evaluation for seedling emergence and vigour. Crop Science 2: 176-177.

NASCIMENTO WM; PEREIRA RS. 2007. Preventing thermo-inhibition in carrot by seed priming. Seed Science and Technology 35: 503-506.

NASCIMENTO WM; CANTLIFFE DJ; HUBER DJ. 2000. Thermotolerance in lettuce seeds: association with ethylene and endo- $\beta$ mannanase. Journal of the American Society for Horticultural Science 125: 518-524.

NASCIMENTO WM; CANTLIFFE DJ; HUBER DJ. 2004. Ethylene evolution and endo$\beta$-mannanase activity during lettuce seed germination at high temperature. Scientia Agricola 61: 156-163.

NASCIMENTO WM; CANTLIFFE DJ; HUBER DJ. 2005. Seed aging affects ethylene production and endo- $\beta$-mannanase activity during lettuce seed germination at high temperature. Seed Science and Technolog 33: 11-17.

NASCIMENTO WM; VIEIRA JV; SILVA GO; REISTMA KR; CANTLIFFE DJ. 2008. Carrot seed germination at high temperature: effect of genotype and association with ethylene production. HortScience 43: 1538-1543.

NASCIMENTO WM; HUBER DJ; CANTLIFFE DJ. 2013. Carrot seed germination and 
respiration at high temperature in response to seed maturity and priming. Seed Science and Technology 41: 164-169.

PEREIRA RS; NASCIMENTO WM; VIEIRA JV. 2007. Germinação e vigor de sementes de cenoura sob condições de altas temperaturas. Horticultura Brasileira 25: 215-219. SIRIWITAYAWAN G; DUTT M; KESTER S;
DOWNIE B; GENEVE R. 2003. Ageing in tomato reduces the capacity of seeds to produce ethylene, whyle priming increases ethylene evolution during germination. The biology of seeds: Recent Research Advances, CAB International. p.441- 446 .

SZAFIROWSKA A; KHAN AA; PECK NH.

1981. Osmoconditioning of carrot seeds to improve seedling establishment and yield in cold soil. Agronomy Journal 73: 845-848.

VIEIRA JV; CRUZ CD; NASCIMENTO WM; MIRANDA JEC. 2005. Seleção de progênies de meio-irmãos de cenoura baseada em características de sementes. Horticultura Brasileira 23: 44-47. 